\title{
ILMU EKONOMI
}

\section{A. Pengertian Ilmu Ekonomi}

Istilah ekonomi berasal dari bahasa Yunani oikonomia. Oikos berarti rumah tangga, sedangkan nomos berarti aturan. Oikonomia mengandung arti aturan yang berlaku untuk memenuhi kebutuhan hidup dalam suatu rumah tangga.

Paul A. Samuelson mendefinisikan ilmu ekonomi sebagai suatu studi tentang perilaku orang dan masyarakat dalam memilih cara menggunakan sumber daya yang langka dan memiliki beberapa alternatif penggunaan, dalam rangka memproduksi berbagai komoditas untuk kemudian menyalurkannya, baik saat ini maupun di masa depan kepada berbagai individu dan kelompok yang ada dalam suatu masyarakat.

Dari definisi di atas, dapat disimpulkan bahwa ilmu ekonomi dari kehidupan sehari-hari menyangkut hal-hal berikut :

a. Ekonomi sangat erat kaitannya dengan perilaku individu dan masyarakat.

b. Adanya sumber daya yang langka, tetapi memiliki beberapa alternatif penggunaan

c. Kegiatan ekonomi terdiri dari produksi, distribusi (penyaluran), dan konsumsi.

d. Konsumen bisa saja dalam bentuk masyarakat, kelompok tertentu atau individu. 


\section{B. Konsep Dasar Ilmu Ekonomi}

1. Kebutuhan

a. Pengertian Kebutuhan

Kebutuhan adalah perasaan kekurangan yang berasal dari dalam diri manusia terhadap barang atau jasa yang dapat memberikan kepuasan kepada manusia itu sendiri, baik kepuasan jasmani maupun rohani. Misalnya, seorang merasa lapar, maka ia harus memenuhi kebutuhan tersebut dengan makan.

b. Jenis Kebutuhan

Kebutuhan dapat dibedakan menurut intensitas, sifat, waktu, dan subjek yang membutuhkannya.

1) Jenis Kebutuhan Berdasarkan Intensitas

Berdasarkan intensitasnya, kebutuhan dibedakan menjadi kebutuhan primer, sekunder, dan Lersier. Dasar yang digunakan adalah peranan kebutuhan tersebut terhadap kelangsungan hidup manusia. Artinya, jika suatu kebutuhan sangat erat kaitannya dengan kelangsungan hidup manusia, maka kebutuhan tersebut adalah kebutuhan primer. Semakin jauh kaitannya dengan kelangsungan hidup manusia, maka tingkatannya menjadi kebutuhan sekunder atau tersier.

\section{2) Jenis Kebutuhan Berdasarkan Sifat}

Berdasarkan sifatnya, kebutuhan dibedakan atas kebutuhan jasmani dan kebutuhan rohani. Dasar yang digunakan adalah dampak atau pengaruhnya 
kepada diri manusia yang terdiri dari jasmani dan rohani. Kebutuhan jasmani erat kaitannya dengan upaya manusia menjaga atau memperindah jasmani manusia. Kebutuhan tersebut antara lain kebutuhan terhadap makanan, pakaian, sepatu, dan jaket. Kebutuhan rohani adalah berupa upaya manusia untuk memenuhi kepuasan jiwa. Misalnya kebutuhan terhadap nasihat agama.

\section{3) Jenis Kebutuhan Berdasarkan Waktu}

Berdasarkan waktu, kebutuhan dibedakan atas kebutuhan sekarang (saat ini) dan kebutuhan masa yang akan datang. Kebutuhan sekarang dibutuhkan sekarang, sedangkan kebutuhan yang akan datang bisa dipastikan dibutuhkan pada masa yang akan datang. Berdasarkan uraian tersebut, dasar yang digunakan untuk membedakan suatu kebutuhan berdasarkan waktu adalah waktu pemenuhannya.

\section{4) Jenis Kebutuhan Berdasarkan Subyek}

Berdasarkan subyeknya, kebutuhan dibedakan menjadi kebutuhan pribadi atau individu dan kebutuhan kolektif (masyarakat). Dasar pembagiannya adalah siapa yang membutuhkan kebutuhan tertentu, apakah pribadi atau masyarakat. Kebutuhan pribadi adalah kebutuhan seseorang dan pemenuhannya oleh pribadi orang tersebut. Kebutuhan kolektif seperti Puskesmas, jalan raya, serta telepon umum dibutuhkan oleh masyarakat dan masyarakat berupaya memenuhinya, baik dengan swadaya maupun dengan bantuan pemerintah. 


\section{Kelangkaan}

Seperti dinyatakan di atas, sumber daya langka. Ini artinya jumlahnya bukan tanpa batas. Bukannya hanya sumber daya yang langka, tetapi barang dan jasa juga langka karena dihasilkan dari sumber daya yang langka. Hal yang perlu diketahui, meskipun sumber daya tersebut langka, tetapi memiliki alternatif penggunaan. Maksudnya sebuah sumber daya dapat digunakan untuk menghasilkan berbagai keperluan, tidak hanya satu. Misalnya, sumber daya manusia atau tenaga kerja dapat digunakan untuk

menghasilkan padi. Tenaga kerja juga bisa untuk menghasilkan senjata, mainan, mobil, dan banyak lainnya. Ini artinya sumber daya bukan hanya bisa menghasilkan satu produk, tetapi sangat banyak karena memiliki alternatif penggunaan.

Ilmu ekonomi sebenarnya membahas kelangkaan. Kelangkaan ini mencakup jumlah, kualitas, tempat, dan waktu. Sesuatu disebut langka karena jumlahnya terbatas. Sesuatu tidak disebut langka jika jumlahnya berlimpah, bermutu baik, dan dapat ditemukan di segala tempat dan waktu. Contoh nyatanya adalah udara. Udara tidak langka karena bisa ada di mana saja dan jumlahnya sangat banyak. Namun udara bersih makin langka di perkotaan karena banyaknya polusi udara. Ini artinya udara secara umum tidaklah langka, tetapi udara bersih justru langka tergantung tempat dan waktunya.

Kelangkaan sumber daya merupakan hal yang pasti dihadapi manusia. Oleh karena langka, manusia harus berpikir dengan cermat dalam menggunakan sumber 
daya. Tanah langka karena luasnya terbatas. Di atas tanah tersebut bisa didirikan apa saja.

Misalnya rumah, gedung perkantoran, lapangan sepak bola, atau untuk pertanian. Kini banyak tanah yang digunakan untuk mendirikan pabrik dan gedung perkantoran akibatnya makin sedikit tanah yang tersedia untuk lahan pertanian. Jika makin sedikit tanah yang tersedia untuk lahan pertanian, makin sedikit pula hasil pertanian yang diperoleh. Harga produk pertanian pun terus meningkat karena persediaannya yang sedikit.

Kelangkaan juga dialami oleh tenaga kerja terutama menyangkut waktu mereka dalam bekerja. Jika tenaga kerja telah memilih satu pekerjaan tertentu, ia tidak bisa lagi bekerja di tempat lain pada waktu yang sama. Namun, meskipun sumber daya tersebut langka, sumber daya tersebut memiliki alternatif penggunaan. Dengan adanya alternatif penggunaan, maka manusia bisa melakukan pilihan referensi.

\section{Alat Pemuas Kebutuhan}

1) Pengertian alat pemuas kebutuhan

Alat pemuas kebutuhan adalah segala sesuatu yang secara langsung maupun tidak langsung dapat memenuhi kebutuhan manusia. Adapun bentuknya, dapat berupa barang atau jasa. Makna barang adalah alat pemuas kebutuhan yang berbentuk benda yang dapat dilihat dan diraba. Contoh barang sebagai alat pemuas, misalnya seorang ibu berniat membuat kue. Ia baru memilki terigu, margarin, dan telur. Ia akan merasa puas jika sudah mendapatkan gula pasir. Kebutuhan gula pasir telah terpenuhi, ibu merasa puas. Jasa adalah alat pemuas 
kebutuhan yang bersifat abstrak (tidak berwujud), tetapi perbuatan atau kegiatannya dapat dirasakan dan dimanfaatkan manusia. Contoh jasa sebagai alat pemuas, misalnya ayah pergi ke kantor tapi tidak memiliki kendaraan. Ayah memerlukan jasa orang lain yang dapat mengantarkannya ke kantor, misalnya naik angkutan kota (angkot). Apabila ayahn telah menikmati jasa angkot dan tiba di kantor tepat waktu, baru ayah merasa puas.

2) Macam-macam alat pemuas

kebutuhan Alat pemuas kebutuhan dapat digolongkan berdasarkan wujud, kelangkaan, tujuan penggunaan, hubungan dengan barang lain, dan sifatnya. Penulis menguraikan satu persatu macam-macam alat pemuas kebutuhan.

a. Alat pemuas kebutuhan menurut wujud

Menurut wujud terbagi menjadi dua bagian, sebagai berikut:

a) Barang konkret, yaitu segala sesuatu dalam alam yang berwujud serta dapat dilihat, diraba. Misalnya, makanan, pakaian, rumah, mobil televisi dan lain-lain.

b) Jasa ialah alat pemenuhan / pemuas kebutuhan manusia yang tidak berwujud, tetapi dapat dirasakan oleh yang memanfaatkannya. Misalnya, jasa dokter, jasa tukang jahit, jasa angkutan/transprotasi, jasa guru, dan lain-lain.

b. Alat pemuas kebutuhan menurut kelangkaan

Menurut kelangkaannya, alat pemuas kebutuhan meliputi tiga jenis barang berikut: 
a) Barang bebas atau barang nonekonomi yaitu barang yang dapat diperoleh tanpa pengorbanan dan jumlahnya tidak terbatas. Contohnya, air, udara, dan sinar matahari.

b) Barang ekonomi yaitu barang yang jumlahnya terbatas dan untuk memperolehnya perlu pengorbanan tertentu. Contohnya, makanan, minuman, pakaian, kendaraan, obat- obatan, rumah atau alat-alat sekolah, dan lain sebagainya.

c. Barang illith yaitu barang yang jumlahnya berlebihan dan harus dikurangi. Contoh : air pada waktu banjir, dan api pada saat terjadi kebakaran.

Alat pemuas kebutuhan menurut tujuan penggunaannya. Menurut tujuan penggunaannya, alat pemuas kebutuhan meliputi dua jenis barang berikut:

a) Barang konsumsi yaitu barang yang dapat langsung digunakan manusia untuk memenuhi kebutuhannya. Contohnya, makanan, minuman, sepatu, obat-obatan, jasa angkut, penyewaan buku, dan lain-lain.

b) Barang modal yaitu barang yang dapat digunakan untuk menghasilkan barang lain dalam kegiatan produksi. Contohnya, mesin cetak, mesin traktor, mesin tenun, mesin jahit, dan lain-lain. 
d. Alat pemuas kebutuhan menurut hubungan dengan barang lain

Menurut hubungan dengan barang lain, alat pemuas kebutuhan meliputi dua jenis barang berikut:

a) Barang subtitusi atau pengganti, yaitu barang kebutuhan manusia yang dalam pemakaiannnya dapat saling mengganti. Contohnya beras dapat diganti dengan jagung kompor gas dapat diganti dengan kompor minyak, mesin tik elektrik dapat di ganti dengan mesin tik manual.

b) Barang komplementer yaitu barang yang dapat berguna jika digabungkan dengan barang lain. Contonya, mesin tenun untuk menenun benang untuk menjadi kain, kopi akan lebih nikmat dan bermanfaat apabila digunakan bersama dengan gula, nasi dimakan bersama lauk pauknya atau sayur, sepeda motor akan bermanfaat apabila diberi bensin, kompor dengan minyak, dan lain-lain.

e. Alat pemuas kebutuhan menurut sifatnya.

Menurut sifat, alat pemuas kebutuhan meliputi dua jenis barang berikut:

a) Barang tetap atau barang tidak bergerak yaitu barang yang tidak dapat dipindah-dipindahkan tempatnya. Contohnya gedung, mesin, rumah, tanah, dan lain-lain.

b) Barang bergerak yaitu barang yang dapat dipindahdipindahkan. Contohnya, perhiasan, sepeda motor, peralatan rumah tangga, bis, truk, dan surat-surat berharga. 


\section{DAFTAR PUSTAKA}

Fadilla, F. (2017). Permasalahan Ekonomi Sesungguhnya Dalam Islam. Islamic Banking: Jurnal Pemikiran Dan Pengembangan Perbankan Syariah, 3(1), 1-10.

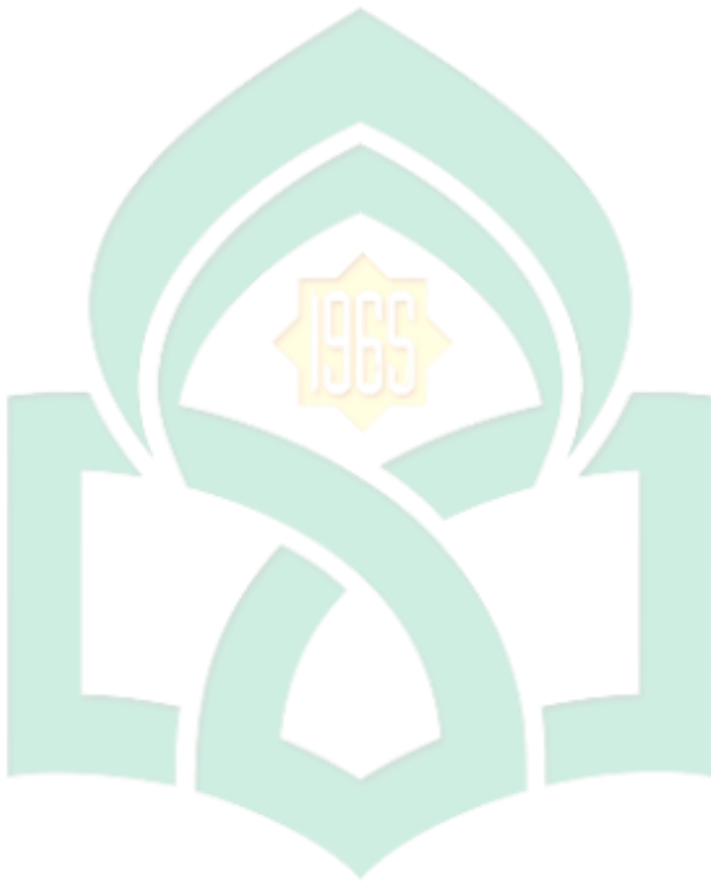

UMNMERSITAS ISLAWU MEGERU

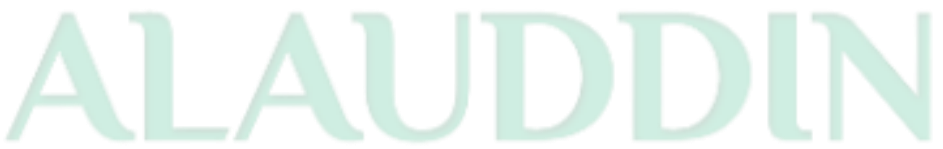

